\title{
Prevalence of hepatitis B virus (HBV) infection in Singapore men with sexually transmitted diseases and HIV infection: role of sexual transmission in a city state with intermediate HBV endemicity
}

\author{
B H Heng, K T Goh, R Chan, S K Chew, S Doraisingham, G H Quek
}

Quarantine and Epidemiology Department, Ministry of the Environment, 40 Scotts Road, Singapore 0922 B H Heng K T Goh

G H Quek

\section{Department of} STD Control, National Skin Centre, Singapore

R Chan

Communicable Disease Centre Ministry of Health, Singapore S K Chew

Pathology Department, Singapore General Hospital, Singapore S Doraisingham

Correspondence to: Dr B H Heng.

Accepted for publication September 1994

\begin{abstract}
Study objectives - To describe the prevalence of hepatitis $B$ virus (HBV) infection in patients with sexually transmitted diseases (STD) and human immunodeficiency virus (HIV) infection, and to determine the role of sexual transmission of $\mathrm{HBV}$ infection in Singapore.

Design - A cross sectional study of all consecutive men presenting with a new episode of STD at a government outpatient clinic and all men with HIV infection on routine follow up at a government hospital. The prevalence of various $\mathrm{HBV}$ markers was compared with that of healthy males aged 15 years and above (controls).
\end{abstract}

Setting - Singapore, a city state of intermediate HBV endemicity.

Subjects - These comprised 497 STD patients, $47 \mathrm{HIV}$ infected patients, and 418 controls.

Main results - The overall seroprevalences of HBV infection in STD patients, HIV infected patients, and control subjects were $41 \cdot 2 \%, 61 \cdot 7 \%$, and $33 \cdot 3 \%$, respectively $(p<0 \cdot 001)$. The seroprevalences of hepatitis $B$ surface antigen $(6 \cdot 2 \%, 8 \cdot 5 \%$, and $4 \cdot 5 \%$, respectively) were comparable in the three groups. Using stepwise logistic regression analysis, the adjusted seroprevalences of HBV infection in STD and HIV infected patients were respectively $2 \cdot 4$ times $(95 \%$ confidence interval $(\mathrm{CI}), 1 \cdot 7$, $3 \cdot 3)$ and 3.3 times $(95 \%$ CI 1.7, 6.3) higher than in controls. HBV infection rates were higher among Chinese (odds ratio (OR), 1.9; 95\% CI 1.6, 3.4) than non-Chinese, and among those aged 25-34 years (OR 2.4; 95\% CI 1.6, 3.4), 35-44 years (OR 3.9; $95 \%$ CI $2 \cdot 5,5 \cdot 9$ ), and $45+$ years (OR 6.2; $95 \%$ CI $3.8,10 \cdot 2$ ) than in those aged 15-24 years. Sex related factors significantly associated with higher infection rates, independent of age and ethnic group, were reactive VDRI test (OR 2.4; 95\% CI 1.2, $4 \cdot 7)$, participation in anal intercourse (OR 2.3; 95\% CI $1 \cdot 2,4 \cdot 3)$, and having 10 or more lifetime sexual partners (OR $1 \cdot 5 ; 95 \%$ CI, 1・0, 2.1).

Conclusion - The importance of sexual transmission of $\mathrm{HBV}$ in an area of intermediate HBV endemicity was con- firmed. Patients attending STD clinics should be routinely screened for HBV markers and those found to be seronegative should be strongly advised to be immunised against this virus.

(f Epidemiol Community Health 1995;49:309-313)

Hepatitis B has been recognised as an important sexually transmitted disease. ${ }^{1}$ Extensive epidemiological studies relating to the sexual transmission of hepatitis B virus (HBV) have been conducted in the low HBV endemic countries of North America and western Europe. ${ }^{2-12}$ Its role in countries of intermediate and high HBV endemicity, however, is not so clear. This is because in endemic countries, up to $80 \%$ of the population may already have been infected before reaching a sexually active age.$^{13}$ Evidence on sexual transmission is therefore difficult to obtain. In Sudan, a serosurvey among prostitutes failed to show the significance of sexual transmission of HBV. ${ }^{14}$ Based on serological studies of household contacts in Taiwan, ${ }^{15}$ China, ${ }^{16}$ Hong Kong, ${ }^{17}$ and the Middle East, ${ }^{18}$ it was concluded that sexual transmission of HBV infection by spouses is of little significance. However, a recent study on acute hepatitis B cases conducted in Taiwan, a country highly endemic for HBV, convincingly showed the importance of heterosexual transmission. ${ }^{19}$

Singapore is a city state of intermediate HBV endemicity with an overall hepatitis $B$ surface antigen (HBsAg) carrier rate of $5 \%$ and $\mathrm{HBV}$ infection rate of about $25 \%$ in the general population. ${ }^{20}$ The role that sexual transmission of HBV plays has not been fully evaluated and is probably underestimated. Serological surveys showed a sharp increase in HBV prevalence in adolescents and young adults. Among family members of acute hepatitis B cases, the prevalence of $\mathrm{HBV}$ infection in spouses $(73 \%)$ was significantly higher than that in siblings, offspring, and other blood relatives, ${ }^{21}$ and spouses of hepatitis $\mathrm{B}$ e antigen $(\mathrm{HBeAg})$ positive women had a higher seroprevalence of HBsAg and antibody to hepatitis B surface antigen (anti-HBs) than those who were HBeAg negative. Among male and female prostitutes, the prevalence of HBV infection was significantly associated with the duration of prostitution. ${ }^{22}$ 
We conducted a cross sectional seroprevalence survey of HBV infection among patients with STD and HIV infection, and provide epidemiological evidence on the importance of sexual transmission of $\mathrm{HBV}$ infection in Singapore.

\section{Methods}

STUDY POPULATIONS

All consecutive male patients presenting with a new episode of STD at a government outpatient clinic and all sexually infected HIV positive patients on routine follow up at a government hospital during the period September 1990 to June 1992, were recruited into the study. Those with a history of HBV immunisation were excluded. Blood was taken from each individual after consent had been obtained. Relevant epidemiological information obtained at the time of blood collection included age, sex, ethnic group, highest educational level attained, past medical history, and history of parenteral procedures. Specific details on sexual behaviour such as sexual orientation (homosexual, bisexual, or heterosexual), type of sexual intercourse practised (vaginal, anal, or both), sexual role (insertive, receptive, or both), type of sexual partner(s) in the previous 12 months (spouse/regular partner, casual, or prostitutes), number of lifetime STD episodes, and number of lifetime sexual partners, were also obtained using a structured questionnaire. As every patient attending the STD clinic would have had a routine blood test for syphilis (VDRL test), medical records of all study participants were also checked for serological evidence of syphilis - that is reactive VDRL test.

The seroprevalence of various HBV markers in STD and HIV infected patients was compared with that of an apparently healthy population group (control group). These comprised male students aged 15 years and above and healthy male government employees whose blood was collected for other health surveys in 1990 and 1991. None had a history of immunisation against HBV. Only demographic information was available for the control group, and details of sexual behaviour were not elicited.

\section{TEST METHOD}

Blood was despatched at the end of each day's collection to the Department of Pathology, Singapore General Hospital. The sera were separated, transferred to polypropylene tubes, and stored in the freezer at $-20^{\circ} \mathrm{C}$ before being tested in batches. Specimens were tested by enzyme immunoassay for $\mathrm{HBsAg}$, total antibody to hepatitis $B$ core antigen (anti-HBc), and anti-HBs using commercial kits (Auszyme Monoclonal, Corzyme, and Ausab EIA, respectively; Abbott Laboratories). Sera positive for $\mathrm{HBsAg}$ were also tested for $\mathrm{HBeAg}$ and anti-HBc IgM (HBe [rDNA] EIA and IMx Core- $M$, respectively). The manufacturer's criteria were used to grade the sera as positive or negative.

\section{DEFINITIONS AND ASSUMPTIONS}

A regular partner was defined as a person with whom the respondent had had sexual intercourse three times or more in the previous three months. A person other than the wife or regular partner with whom the respondent had sex was considered a casual partner, while a prostitute was one who offered sex in exchange for money. It was assumed that marriages and regular partnerships were stable relationships, and any act of sexual intercourse outside of marriage/regular partnership carried some risk.

\section{STATISTICAL ANALYSIS}

The microcomputer based Statistical Analysis Systems (SAS) software was used for data analysis. Differences in proportions observed were initially compared by $\chi^{2}$ tests with Yates's continuity correction and probability values less than 0.05 were considered significant. To determine whether or not the seroprevalence of STD patients and HIV infected patients was significantly higher than that of control population, while adjusting for possible confounders, stepwise multiple logistic regression was performed on the three comparison groups. In the model, seropositivity for any HBV marker was the outcome variable, STD and HIV patients the independent covariates, and the control population the reference category. Other potentially confounding covariates included in the regression model were age, sex, ethnic group, educational level, and history of parenteral procedures in the previous six months. Similarly, to identify risk factors associated with increased seroprevalence, stepwise logistic regression was carried out on STD and HIV infected patients. Additional independent covariates included in the model were sexual orientation (homo/bisexual $v$ heterosexual), sexual practices (anal or anal and vaginal $v$ vaginal), sexual role (receptive or receptive and insertive $v$ insertive), number of lifetime STD episodes (three or more $v$ fewer than three), number of lifetime sexual partners (10 or more $v$ fewer than 10), and VDRL seroreactivity (reactive $v$ non-reactive). Logistic regression analysis with seropositivity for HBsAg as the outcome variable was carried out similarly, using the same covariates in the models. As virtually all patients had had contact with either casual acquaintances or prostitutes, or both, in the previous year, the type of sexual contact as a covariate was not included in the analyses.

\section{Results}

DESCRIPTION OF DATA

A total of 497 STD patients, $47 \mathrm{HIV}$ infected patients, and 418 control subjects were tested for various $\mathrm{HBV}$ markers. None of the subjects were intravenous drug users. The prevalence of various HBV markers in the three comparison groups is shown in table 1 . The prevalence of $\mathrm{HBV}$ infection (any HBV marker positive) in relation to age, ethnicity, and educational level is given in table 2, and the prevalence of $\mathrm{HBV}$ infection in the STD and HIV infected patients 
Table 1 Prevalence of various markers of hepatitis $B$ virus (HBV) infection in patients with sexually transmitted diseases (STD), human immunodeficiency virus infection (HIV) and healthy individuals (control) in Singapore

\begin{tabular}{|c|c|c|c|c|}
\hline Marker & $\begin{array}{l}S T D \\
(n=497) \\
N o(\%)\end{array}$ & $\begin{array}{l}H I V \\
(n=47) \\
\text { No (\%) }\end{array}$ & $\begin{array}{l}\text { Control } \\
(n=418) \\
\text { No (\%) }\end{array}$ & $\begin{array}{l}p \\
\text { value* }\end{array}$ \\
\hline $\begin{array}{l}\text { HBsAg } \\
\text { HBeAg } \\
\text { Anti-HBc IgM } \\
\text { Anti-HBc, total } \\
\text { Anti-HBs } \\
\text { Any HBV marker }\end{array}$ & $\begin{array}{r}31(6 \cdot 2) \\
8(1 \cdot 6) \\
3(0 \cdot 6) \\
175(35 \cdot 2) \\
155(31 \cdot 2) \\
205(41 \cdot 2)\end{array}$ & $\begin{array}{r}4(8 \cdot 5) \\
1(2 \cdot 1) \\
0(0) \\
22(46 \cdot 8) \\
19(40 \cdot 5) \\
29(61 \cdot 7)\end{array}$ & $\begin{array}{r}19(4 \cdot 5) \\
3(0 \cdot 7) \\
\text { ND } \\
116(27 \cdot 8) \\
86(20 \cdot 6) \\
139(33 \cdot 3)\end{array}$ & $\begin{array}{l}\text { NS } \\
\text { NS } \\
-0.006 \\
<0 \cdot 001 \\
<0.001\end{array}$ \\
\hline
\end{tabular}

${ }^{*}$ By $\chi^{2}$ test with Yates's continuity correction

NS $p \geq 0.05$.

ND not done. in relation to various risk factors is shown in table 3.

Most STD patients (465 or $94 \%$ ) had had sex with casual partners or prostitutes, or both, in the previous year. Of the 211 who were married or had regular partners, $173(82 \%)$ had had sex concurrently with their spouses or regular partners in the previous year. Of these extramarital/extra-regular partnership sexual encounters, $129(75 \%)$ were with prostitutes.

Eight of $31(25 \cdot 8 \%)$ STD patients who were $\mathrm{HBsAg}$ positive were $\mathrm{HBeAg}$ positive. All eight

Table 2 Seroprevalence (\%) of hepatitis B virus (HBV) markers in relation to age, ethnicity, and educational level in patients with sexually transmitted diseases (STD), HIV infection (HIV) and healthy individuals (control) in Singapore

\begin{tabular}{|c|c|c|c|c|c|c|c|c|c|}
\hline & \multicolumn{3}{|c|}{$S T D$} & \multicolumn{3}{|c|}{$H I V$} & \multicolumn{3}{|c|}{ Control } \\
\hline & No & $H B s A g+v e$ & $H B V+v e$ & No & $H B s A g+v e$ & $H B V+v e$ & No & $H B s A g+v e$ & $H B V+v e$ \\
\hline All & 497 & $6 \cdot 2$ & $41 \cdot 4$ & 47 & $8 \cdot 5$ & $59 \cdot 6$ & 418 & 4.5 & $33 \cdot 2$ \\
\hline $\begin{array}{l}\text { Age group (y): } \\
\text { 15-24 } \\
25-34 \\
35-44 \\
45+ \\
\text { Unknown }\end{array}$ & $\begin{array}{r}211 \\
187 \\
67 \\
31 \\
1\end{array}$ & $\begin{array}{r}4 \cdot 7 \\
6 \cdot 4 \\
11 \cdot 9 \\
3 \cdot 2 \\
0\end{array}$ & $\begin{array}{c}28 \cdot 3 \\
44 \cdot 9 \\
64 \cdot 2 \\
61 \cdot 3 \\
0\end{array}$ & $\begin{array}{r}6 \\
21 \\
18 \\
2 \\
0\end{array}$ & $\begin{array}{l}0 \\
19 \cdot 0 \\
0 \\
0 \\
0\end{array}$ & $\begin{array}{c}50 \cdot 0 \\
61 \cdot 9 \\
55 \cdot 6 \\
100 \\
0\end{array}$ & $\begin{array}{r}54 \\
111 \\
137 \\
116 \\
0\end{array}$ & $\begin{array}{l}1 \cdot 9 \\
5 \cdot 4 \\
3 \cdot 6 \\
6 \cdot 0 \\
0\end{array}$ & $\begin{array}{c}11 \cdot 1 \\
25 \cdot 2 \\
35 \cdot 8 \\
48 \cdot 3 \\
0\end{array}$ \\
\hline $\begin{array}{l}\text { Ethnic group: } \\
\text { Chinese } \\
\text { Malay } \\
\text { Indian } \\
\text { Others }\end{array}$ & $\begin{array}{r}347 \\
59 \\
80 \\
11\end{array}$ & $\begin{array}{l}8 \cdot 4 \\
0 \\
1 \cdot 3 \\
9 \cdot 1\end{array}$ & $\begin{array}{l}45 \cdot 2 \\
30 \cdot 5 \\
32 \cdot 5 \\
45 \cdot 5\end{array}$ & $\begin{array}{r}40 \\
4 \\
2 \\
1\end{array}$ & $\begin{array}{c}10 \cdot 0 \\
0 \\
0 \\
0\end{array}$ & $\begin{array}{c}55 \cdot 0 \\
100 \\
50 \cdot 0 \\
100\end{array}$ & $\begin{array}{r}234 \\
120 \\
60 \\
4\end{array}$ & $\begin{array}{l}6 \cdot 8 \\
2 \cdot 5 \\
0 \\
0\end{array}$ & $\begin{array}{c}39 \cdot 3 \\
25 \cdot 8 \\
20 \cdot 0 \\
100\end{array}$ \\
\hline $\begin{array}{l}\text { Highest educational level att } \\
\text { None or primary school } \\
\text { Secondary school } \\
\text { Beyond secondary school }\end{array}$ & $\begin{array}{r}150 \\
291 \\
56\end{array}$ & $\begin{array}{l}4 \cdot 0 \\
7 \cdot 6 \\
5 \cdot 4\end{array}$ & $\begin{array}{l}49 \cdot 3 \\
38 \cdot 1 \\
37 \cdot 3\end{array}$ & $\begin{array}{l}12 \\
21 \\
14\end{array}$ & $\begin{array}{c}0 \\
9 \cdot 5 \\
14 \cdot 3\end{array}$ & $\begin{array}{l}50 \cdot 0 \\
57 \cdot 1 \\
71 \cdot 4\end{array}$ & $\begin{array}{r}274 \\
68 \\
76\end{array}$ & $\begin{array}{r}3.3 \\
10.3 \\
3.9\end{array}$ & $\begin{array}{l}32 \cdot 1 \\
38 \cdot 2 \\
32 \cdot 9\end{array}$ \\
\hline
\end{tabular}

$\mathrm{HBV}+$ ve any $\mathrm{HBV}$ marker positive

Table 3 Seroprevalence of HBV infection in patients with sexually transmitted diseases (STD) and HIV infection (HIV) in relation to various risk factors

\begin{tabular}{|c|c|c|c|c|c|c|c|c|}
\hline \multirow[t]{2}{*}{ Risk factors } & \multicolumn{2}{|l|}{$S T D$} & \multicolumn{2}{|c|}{$H I V$} & \multicolumn{2}{|l|}{ Total } & \multirow[t]{2}{*}{ Odds ratio $(95 \%$ CI) } & \multirow[t]{2}{*}{ p value* } \\
\hline & No & $H B V+v e$ & No & $H B V+v e$ & No & $H B V+v e$ & & \\
\hline All & 497 & $41 \cdot 4$ & 47 & $59 \cdot 6$ & 544 & 44.9 & & \\
\hline $\begin{array}{l}\text { Parenteral procedure in previous } 6 \\
\text { months: } \\
\text { Yes } \\
\text { No }\end{array}$ & $\begin{array}{l}189 \\
308\end{array}$ & $\begin{array}{l}41 \cdot 3 \\
41 \cdot 6\end{array}$ & $\begin{array}{l}22 \\
25\end{array}$ & $\begin{array}{l}63 \cdot 6 \\
56 \cdot 0\end{array}$ & $\begin{array}{l}211 \\
333\end{array}$ & $\begin{array}{l}43 \cdot 6 \\
42 \cdot 6\end{array}$ & $\begin{array}{l}1 \cdot 0(0 \cdot 7,1 \cdot 5) \\
1\end{array}$ & NS \\
\hline $\begin{array}{l}\text { Sexual orientation: } \\
\text { Homo-bisexual } \\
\text { Heterosexual } \\
\text { Unknown }\end{array}$ & $\begin{array}{r}23 \\
473 \\
1\end{array}$ & $\begin{array}{c}6 \cdot 5 \\
40 \cdot 8 \\
0\end{array}$ & $\begin{array}{r}22 \\
25 \\
0\end{array}$ & $\begin{array}{c}72 \cdot 7 \\
48 \cdot 0 \\
0\end{array}$ & $\begin{array}{r}45 \\
498 \\
0\end{array}$ & $\begin{array}{c}64 \cdot 4 \\
41 \cdot 2 \\
0\end{array}$ & $\begin{array}{l}2 \cdot 6(1 \cdot 3,5 \cdot 1) \\
1\end{array}$ & 0.004 \\
\hline $\begin{array}{l}\text { Type of intercourse: } \\
\text { Vaginal only } \\
\text { Anal/anal and vaginal } \\
\text { Oral only } \\
\text { Unknown }\end{array}$ & $\begin{array}{r}462 \\
27 \\
2 \\
6\end{array}$ & $\begin{array}{c}41 \cdot 1 \\
55 \cdot 6 \\
0 \\
16 \cdot 7\end{array}$ & $\begin{array}{r}25 \\
22 \\
0 \\
0\end{array}$ & $\begin{array}{c}48 \cdot 0 \\
72 \cdot 7 \\
0 \\
0\end{array}$ & $\begin{array}{r}487 \\
49 \\
2 \\
6\end{array}$ & $\begin{array}{c}41 \cdot 5 \\
63 \cdot 3 \\
0 \\
16 \cdot 7\end{array}$ & $\frac{1}{2 \cdot 4}(1 \cdot 3,4 \cdot 7)$ & 0.005 \\
\hline $\begin{array}{l}\text { Type of sexual role: } \\
\text { Insertive only } \\
\text { Receptive/receptive and insertive } \\
\text { Unknown }\end{array}$ & $\begin{array}{r}486 \\
5 \\
6\end{array}$ & $\begin{array}{l}54 \cdot 1 \\
40 \cdot 0 \\
16 \cdot 7\end{array}$ & $\begin{array}{r}28 \\
19 \\
0\end{array}$ & $\begin{array}{c}50 \cdot 0 \\
73 \cdot 7 \\
0\end{array}$ & $\begin{array}{r}514 \\
24 \\
6\end{array}$ & $\begin{array}{l}42 \cdot 2 \\
66 \cdot 7 \\
16 \cdot 7\end{array}$ & $\stackrel{1}{2 \cdot 7}(1 \cdot 1,7 \cdot 1)$ & 0.03 \\
\hline $\begin{array}{l}\text { Total no of lifetime STD episodes: } \\
<3 \\
3+\end{array}$ & $\begin{array}{r}422 \\
75\end{array}$ & $\begin{array}{l}38 \cdot 4 \\
58 \cdot 7\end{array}$ & $\begin{array}{r}45 \\
2\end{array}$ & $\begin{array}{c}62 \cdot 2 \\
0\end{array}$ & $\begin{array}{r}467 \\
77\end{array}$ & $\begin{array}{l}40 \cdot 7 \\
57 \cdot 1\end{array}$ & $1.9(1 \cdot 2,3 \cdot 3)$ & $0 \cdot 01$ \\
\hline $\begin{array}{l}\text { Total no of lifetime sexual partners: } \\
<10 \\
10+\end{array}$ & $\begin{array}{l}257 \\
240\end{array}$ & $\begin{array}{l}35 \cdot 0 \\
48 \cdot 3\end{array}$ & $\begin{array}{l}15 \\
32\end{array}$ & $\begin{array}{l}46 \cdot 7 \\
65 \cdot 6\end{array}$ & $\begin{array}{l}272 \\
272\end{array}$ & $\begin{array}{l}35 \cdot 7 \\
50 \cdot 4\end{array}$ & $1 / 8(1 \cdot 3,2 \cdot 6)$ & $<0.001$ \\
\hline $\begin{array}{l}\text { VDRL serology: } \\
\text { Reactive } \\
\text { Non-reactive } \\
\text { Not done }\end{array}$ & $\begin{array}{r}38 \\
442 \\
17\end{array}$ & $\begin{array}{l}63 \cdot 2 \\
39 \cdot 6 \\
41 \cdot 1\end{array}$ & $\begin{array}{r}7 \\
25 \\
15\end{array}$ & $\begin{array}{l}85 \cdot 7 \\
56 \cdot 0 \\
53 \cdot 3\end{array}$ & $\begin{array}{r}45 \\
467 \\
32\end{array}$ & $\begin{array}{l}66 \cdot 7 \\
40 \cdot 5 \\
46 \cdot 9\end{array}$ & $\begin{array}{l}2 \cdot 9(1.5,5 \cdot 9) \\
1\end{array}$ & 0.01 \\
\hline
\end{tabular}

* By $\chi^{2}$ test with Yates's continuity correction.

$\mathrm{HBV}+\mathrm{ve}$ any HBV marker positive.

NS $\mathrm{p} \geq 0.05$. 
Table 4 Variables significantly associated* with hepatitis $B$ virus infectiont among patients with sexually transmitted diseases and HIV infection and healthy individuals (controls) in Singapore

\begin{tabular}{|c|c|c|c|c|}
\hline Variable & $\begin{array}{l}\text { Regression } \\
\text { coefficient }\end{array}$ & $\begin{array}{l}\text { Odds } \\
\text { ratio }\end{array}$ & $(95 \% C I)$ & $\begin{array}{l}p \\
\text { value }\end{array}$ \\
\hline \multicolumn{5}{|l|}{$\begin{array}{l}\text { Whole sample } \\
(\mathrm{n}=962)\end{array}$} \\
\hline $\begin{array}{l}\text { Age group }(y): \\
25-34 \\
35-44 \\
45+ \\
{[15-24]}\end{array}$ & $\begin{array}{l}0.85 \\
1.35 \\
1.83\end{array}$ & $\begin{array}{l}2 \cdot 4 \\
3 \cdot 9 \\
6 \cdot 2\end{array}$ & $\begin{array}{l}(1 \cdot 6,3 \cdot 4) \\
(2 \cdot 5,5 \cdot 9) \\
(3 \cdot 8,10 \cdot 2)\end{array}$ & $\begin{array}{l}<0.0001 \\
<0.0001 \\
<0.0001\end{array}$ \\
\hline $\begin{array}{l}\text { Ethnic group: } \\
\text { Chinese } \\
\text { [Non-Chinese] }\end{array}$ & $0 \cdot 64$ & 1.9 & $(1 \cdot 4,2 \cdot 6)$ & $<0.0001$ \\
\hline $\begin{array}{l}\text { Risk group: } \\
\text { STD patients } \\
\text { HIV infected patients } \\
\text { [Control] }\end{array}$ & $\begin{array}{l}0 \cdot 86 \\
1 \cdot 18\end{array}$ & $\begin{array}{l}2 \cdot 4 \\
3 \cdot 3\end{array}$ & $\begin{array}{l}(1 \cdot 7,3 \cdot 3) \\
(1 \cdot 7,6 \cdot 3)\end{array}$ & $\begin{array}{r}<0.0001 \\
0.0004\end{array}$ \\
\hline \multicolumn{5}{|l|}{$\begin{array}{l}\text { STD and HIV infected patients } \\
(\mathrm{n}=544)\end{array}$} \\
\hline $\begin{array}{l}\text { Age group (y): } \\
25-34 \\
35-44 \\
45+ \\
{[15-24]}\end{array}$ & $\begin{array}{l}0 \cdot 70 \\
1 \cdot 32 \\
1 \cdot 47\end{array}$ & $\begin{array}{l}2 \cdot 0 \\
3 \cdot 8 \\
4 \cdot 3\end{array}$ & $\begin{array}{l}(1 \cdot 3,3 \cdot 1) \\
(2 \cdot 2,6 \cdot 5) \\
(2 \cdot 0,9 \cdot 6)\end{array}$ & $\begin{aligned} 0.001 \\
<0.0001 \\
0.0003\end{aligned}$ \\
\hline $\begin{array}{l}\text { Ethnic group: } \\
\text { Chinese } \\
\text { [non-Chinese] }\end{array}$ & 0.57 & $1 \cdot 8$ & $(1 \cdot 2,2 \cdot 7)$ & 0.007 \\
\hline $\begin{array}{l}\text { Sexual practice: } \\
\text { Anal/anal and vaginal } \\
\text { [vaginal only] }\end{array}$ & 0.83 & $2 \cdot 3$ & $(1 \cdot 2,4 \cdot 3)$ & 0.01 \\
\hline $\begin{array}{l}\text { Total no of lifetime sexual partners: } \\
10+ \\
{[<10]}\end{array}$ & 0.39 & 1.5 & $(1 \cdot 0,2 \cdot 1)$ & 0.04 \\
\hline $\begin{array}{l}\text { VDRL test: } \\
\text { Reactive } \\
\text { [Non-reactive] }\end{array}$ & 0.86 & $2 \cdot 4$ & $(1 \cdot 2,4 \cdot 7)$ & 0.01 \\
\hline
\end{tabular}

${ }^{*} \mathrm{p}<0.05$ by stepwise logistic regression analysis.

t any HBV marker positive.

[ ] reference category.

were heterosexuals with multiple partners (three had had 100 or more lifetime partners). Of the four HIV infected patients who were HBsAg positive, one, a bisexual who had engaged in anal (insertive and receptive) and vaginal intercourse with more than a 100 lifetime partners, was $\mathrm{HBeAg}$ positive. All these nine with $\mathrm{HBeAg}$ were Chinese aged 23-40 years. Three of the STD patients but none of the HIV infected patients were anti-HBc IgM positive.

\section{UNIVARIATE ANALYSIS}

The prevalence of anti-HBc, anti-HBs, and any positive $\mathrm{HBV}$ marker was significantly higher among patients with STD and HIV infection than in the control population (table 1). As expected, the prevalence of $\mathrm{HBV}$ infection increased progressively with age, and it was higher in the Chinese than in the non-Chinese. There was no correlation with educational level (table 2). Risk factors which were significantly associated with higher HBV seroprevalence rates were homo-bisexuality, history of anal intercourse, receptive sexual role, three or more lifetime episodes of STD, 10 or more lifetime sexual partners, and a reactive VRDL test (table 3).

STEPWISE LOGISTIC REGRESSION ANALYSIS The adjusted seroprevalences of STD patients and HIV infected patients were 2.4 times $(95 \%$
CI $1 \cdot 7,3 \cdot 3)$ and $3 \cdot 3$ times (95\% CI $1 \cdot 7,6 \cdot 3)$, respectively, higher than that of the control population (table 4). Two variables - that is, increasing age and Chinese ethnic group - were associated with a high seroprevalence. Among patients with STD and HIV infection, seroprevalence was also significantly associated with the following risk factors: practice of anal intercourse, having 10 or more lifetime sexual partners, and a reactive VDRL test. This association was independent of age and ethnic group. Although the adjusted HBV seroprevalence of HIV infected patients was higher than that of STD patients, the difference was not statistically significant.

The difference in the adjusted seroprevalence of HBsAg among STD patients, HIV infected patients, and controls was not significant. However, the Chinese had a significantly higher adjusted rate compared with the non-Chinese (OR $7 \cdot 2 ; 95 \%$ CI $1 \cdot 7,30 \cdot 5$ ). This association was independent of age. The adjusted prevalence of HBsAg was not associated with any of the variables related to sexual behaviour.

\section{Discussion}

Our study showed that patients with STD and HIV infection in an intermediate HBV endemic area have a significantly higher prevalence of $\mathrm{HBV}$ infection, independent of age and ethnic group, than healthy individuals (controls). Although immunocompromised people have a higher risk of developing the carrier state when 
infected with $\mathrm{HBV},{ }^{23}$ the prevalence of $\mathrm{HBsAg}$ in HIV infected patients $(8.5 \%)$ was not significantly different from that in patients with STD $(6.2 \%)$ and healthy individuals $(4.5 \%){ }^{24-26}$ This is because the number of HIV infected patients was small, and no deduction can be made from the hepatitis $B$ profiles of the few HIV infected patients who were $\mathrm{HBsAg}$ positive. It is also not possible from such a cross sectional serological survey to determine whether HBV infection was acquired before or after HIV infection. We also confirmed the risk factors found to be significantly associated with HBV transmission in areas of low endemicity - that is, multiple sexual partners, ${ }^{511-1227-28}$ anal intercourse, ${ }^{710}$ and positive serology for syphilis..$^{911}$

In Singapore, with the successful implementation of the national childhood immunisation programme against $\mathrm{HBV}$ infection, ${ }^{29}$ perinatal transmission has been reduced by $80 \%$, while horizontal transmission has declined through other public health measures. ${ }^{20}$ Sexual transmission will inevitably emerge as the leading cause of HBV infection among healthy susceptible adolescents and adults as in the west. ${ }^{2-12}$ Routine epidemiological investigations into reported cases of acute hepatitis $B$ showed that more than $98 \%$ occurred in persons aged 15 years and above, with the highest morbidity among those aged 15-34 years. More than $80 \%$ of those with acute hepatitis B had no history of known exposure to percutaneous procedures before the onset of illness. Discreet enquiries also showed that up to $50 \%$ of the cases had had heterosexual contacts, other than with their spouses, especially when they travelled overseas, compared with only $16 \%$ in the general male population. ${ }^{30}$

Based on the findings of the study, we recommend that patients attending STD clinics should be routinely screened for HBV markers and those found to be seronegative should be strongly advised to be immunised against HBV.

We thank the staff of Quarantine and Epidemiology Department, Ministry of the Environment, Department of STD Control, National Skin Centre, and Communicable Disease Centre, Ministry of Health, for their assistance in collecting and collating data for the study.

1 Szmuness W, Much MI, Prince AM et al. On the role of sexual behaviour in the spread of hepatitis B infection. Ann Intern Med 1975:83:489-95.

2 Fulford KWM, Dane DS, Catterall RD, Woof R, Denning JV. Australia antigen and antibody among patients attending a clinic for sexually transmitted disease. Lancet 1973;i:1470-3.

3 Jeffries DJ, James WH, Jefferiss FJG, McLeod KG, Willcox RR. Australia (hepatitis-associated) antigen in patients attending a venereal disease clinic. BMF 1973;ii:455-6.

4 Heathcote JS. Spread of acute type-B hepatitis in London. Lancet 1973;i:1468-70.
5 Lim KS, Wong VT, Fulford WM, Catterall RD, Briggs $M$, Dane DS. Role of sexual and non-sexual practices in the transmission of hepatitis B. Br F Ven Dis 1977;53:190-2.

6. Kryger P, Pedersen NS, Mathiesen L, Nielsen JE. Increased risk of infection with hepatitis $A$ and $B$ viruses in men with a history of syphilis: relation to causal contacts. $\mathcal{F}$ Infect Dis 1982;145:23-6.

7 Schreeder MT, Thompson SE, Hadler SC et al. Hepatitis $B$ in homosexual men: prevalence of infection and factors related to transmission. $\mathcal{F}$ Infect Dis 1982;146:7-15.

8 Tassopoulos NC, Papaevangelou GJ, Roumeliotou-Karayannis A, Ticehurst JR, Feinstone SM, Purcell RH. rayannis A, Ticehurst JR, Feinstone SM, Purcell RH. hetection of hepatitis B virus DNA in asymptomatic transmission. Am $\mathcal{F}$ Epidemiol 1987; 126:587-91.

9 Hyams KC, Escamilla J, Romero RL et al. Hepatitis B infection in a non-drug abusing prostitute population in infection in a non-drug abusing prostitute p
Mexico. Scand $\mathcal{f}$ Infect Dis 1990;22:527-31.

10 Kingsley LA, Rinaldo CR Jr, Lyter DW, Valdiserri RO, Belle $\mathrm{SH}$, Ho M. Sexual transmission efficiency of hepatitis B virus and human immunodeficiency virus among homosexual men. $\mathcal{F} A M A$ 1990;264:230-4.

11 Rosenblum LS, Hadler SC, Castro KG, Lieb S, Jaffe HW. Heterosexual transmission of hepatitis B virus in Belle Glade, Florida. $\mathcal{F}$ Infect Dis 1990;161:407-11.

12 Struve J, Kall K, Stendahl P, Scalia-Tomba G, Giesecke J, Wriland $O$. Prevalence of hepatitis $B$ virus markers among intravenous drug abusers in Stockholm: impact of hetintravenous drug abusers in Stockholm: impact of het-

13 Whittle HC, Bradley AK, McLauchlan K 1993 ;25:8-13. virus infection in two Gambian villages. Lancet 1983;i: virus infect 6 .

14 McCarthy MC, Burans JP, Constantine NT et al. Hepatitis $B$ and HIV in Sudan: a serosurvey for hepatitis B and h and Hron in Sudan: a serosurvey for hepatitis B and human immunodeficiency virus antibodies among sexually

15 Sung JL. Hepatitis B virus infection and its sequelae in Taiwan. Proc Natl Sci Counc 1981;5:385-99.

$16 \mathrm{Liu}$ CB, Lee Y, Hu ZH. Familial clustering of HBsAg in China. In: Mackenzie JC ed. Viral diseases in south-east Asia and the western Pacific. Sydney: Sydney Academic Press, 1982;366-70.

17 Lok ASF, Lai CL, Wu PC, Wong VCW, Yeoh EK, Lin HJ. Hepatitis B virus infection in Chinese families in Hong Kong. Am $\mathcal{F}$ Epidemiol 1987;126:492-9.

18 Toukan AU, Sharaiha ZK, Abu-El-Rib OA et al. The epidemiology of hepatitis $B$ virus among family members in the Middle East. Am $\mathcal{F}$ Epidemiol 1990;132:220-32.

19 Hou MC, Wu JC, Kuo BIT et al. Heterosexual transmission as the most common route of acute hepatitis $B$ virus infection among adults in Taiwan - the importance of extending vaccination to susceptible adults. $\mathcal{F}$ Infect Dis 1993;167:938-41.

20 Goh KT. Epidemiology and control of hepatitis B virus infection in Singapore. Tokyo: Southeast Asian Medical Information Center, 1992.

21 Goh KT, Ding JL, Monteiro EH, Oon CJ. Hepatitis B infection in households of acute cases. $\mathcal{F}$ Epidemiol Com munity Health 1985;39:123-8.

22 Goh CL, Rajan VS, Chan SH, Kamarudin A. Hepatitis B infection in prostitutes. Int $\mathcal{f}$ Epidemiol 1986;15:112-5.

23 Hadler SC, Judson FN, O'Malley PM et al. Outcome of hepatitis B virus infection in homosexual men and its relation to prior human immunodeficiency virus infection. F Infect Dis 1991;163:454-9.

24 Hyams KC, Phillips IA, Tejada A et al. Hepatitis B in a highly active prostitute population: evidence for a low risk of chronic antigenemia $\mathcal{Y}$ Infect Dis 1990;162:295-8.

25 Chen CJ, Hwang SJ, Fan KY. Seroepidemiology of human $T$ lymphotropic viruses and hepatitis viruses among proTymphotropic viruses and hepatitis viruses among
stitutes in Taiwan. $\mathcal{F}$ Infectious Dis 1988;158:633-5.

26 Papaevangelou G, Trichopoulos D, Kremastinou T, Papoutsakis G. Prevalence of hepatitis $B$ antigen and antibody in prostitutes. BMF 1974;50:256-8.

27 Alter MJ, Coleman PJ, Alexander WJ et al. Importance of heterosexual activity in the transmission of hepatitis $B$ and non-A, non-B hepatitis. $\mathcal{F} A M A$ 1989;262:1201-5

28 Baddour LM, Bucak VA, Somes RNG, Hudson R. Risk factors for hepatitis $B$ virus infection in black female attendees of a sexually transmitted disease clinic. Sex Transm Dis 1988;15:174-6.

29 Goh KT, Doraisingham S, Tan KL et al. The hepatitis B immunization programme in Singapore. Bull World Healt Organ 1989;67:65-70.

30 Heng BH, Lee HP, Kok LP, Ong YW, Ho ML. A survey of sexual behaviour of Singaporeans. Ann Acad Med Singapore 1992;21:724-9. 